Palimpsest: Journal of Information and Library Science Vol. 12, Issue 1, 2021, page 1-11

\title{
Prosedur Perbaikan untuk Mengontrol dan Meminimalkan Varians Metode Umum dalam Survei Penelitian Perpustakaan dan Ilmu Informasi
}

\section{Procedural Remedies for Controlling and Minimizing Common Method Variance in Survey in Library and Information Science Research}

\author{
Mohamad Noorman Masrek ${ }^{1}$, Heriyanto ${ }^{2}$ \\ Faculty of Information Management, Universiti Teknologi MARA, Malaysia. \\ mnoorman@uitm.edu.my ${ }^{1}$, Fakultas Ilmu Budaya, Universitas Diponegoro, Indonesia ${ }^{2}$
}

Received : 27 $7^{\text {th }}$ January 2021; Revised : 27 $7^{\text {th }}$ April 2021 ; Accepted : $27^{\text {th }}$ May 2021

Available Online : 20 ${ }^{\text {th }}$ June 2021; Published Regularly : 20 June 2021

\begin{abstract}
Producing valid and reliable research findings is the responsibility of every researcher. Research findings that are valid and reliable will be useful and beneficial to all stakeholders of the research. Research findings should have significant contribution to the body of knowledge from theoretical, practical, and empirical perspectives. Common Method Variances (CMV) are threats to producing valid and reliable research findings. Many quantitative survey researches done in the domain of library and information science failed to incorporate the necessary mechanism to control and minimize CMV. The aim of this paper is therefore to bridge the knowledge gap by describing CMV as a central theme in library research. It describes the sources of CMV and the appropriate procedural remedies that can be adopted for controlling and minimizing CMV. As far as the research methodology is concerned, the study adopted an integrative literature review approach. The application of a range of preventive procedures discussed in this paper should serve as an effective measure to deal with CMV to provide valid findings in the field of library theory and information science.
\end{abstract}

Keywords: Common method variance; quantitative methodology; survey

\begin{abstract}
Abstrak
Menghasilkan temuan penelitian yang valid dan dapat dipercaya menjadi tanggung jawab setiap peneliti. Temuan penelitian yang valid dan reliabel akan berguna dan bermanfaat bagi semua pemangku kepentingan yang terlibat dalam penelitian. Temuan penelitian harus memiliki kontribusi yang signifikan terhadap kumpulan pengetahuan dari perspektif teoritis, praktis, dan empiris. Varians Metode Umum atau Common Method Variances (CMV) adalah tanda untuk menghasilkan temuan penelitian yang valid dan dapat dipercaya. Banyak penelitian survei kuantitatif yang dilakukan dalam domain Ilmu Perpustakaan dan Informasi gagal menggabungkan mekanisme yang diperlukan untuk mengontrol dan meminimalkan CMV. Oleh karena itu, tujuan dari penelitian ini adalah untuk menjembatani kesenjangan pengetahuan dengan menggambarkan CMV sebagai tema sentral dalam penelitian perpustakaan. Kajian ini menjelaskan sumber CMV dan solusi prosedural yang tepat yang dapat digunakan untuk mengendalikan dan meminimalkan CMV. Sejauh menyangkut tentang metodologi penelitian, studi ini mengadopsi sebuah pendekatan tinjuan pustaka secara integratif. Penerapan berbagai prosedur pencegahan yang dibahas dalam tulisan ini berfungsi sebagai ukuran yang efektif untuk menangani CMV, sehingga dapat menghasilkan temuan yang valid dibidang teori kepustakan dan ilmu informasi.
\end{abstract}

Kata kunci: Varians metode umum; metodologi kuantitatif; survei

\section{Pendahuluan}


Survei merupakan metode penelitian kuantitatif yang paling dominan digunakan dalam penelitian perpustakaan. Istilah survei digunakan dalam berbagai hal, tetapi biasanya mengacu pada pemilihan sampel orang yang relatif besar dari populasi yang telah ditentukan sebelumnya, diikuti dengan pengumpulan sejumlah kecil data dari individu tersebut. Oleh karena itu, peneliti menggunakan informasi dari sampel individu untuk membuat kesimpulan tentang populasi yang lebih luas. Dalam penelitian survei, kuesioner merupakan teknik pengumpulan data yang paling sering digunakan.

Terlepas dari popularitasnya, metode survei menghadirkan tantangan metodologi yang serius, yaitu risiko Varians Metode Umum (CMV). Banyak peneliti di bidang perpustakaan dan ilmu informasi masih belum menyadari masalah ini. CMV adalah varians yang terkait dengan metode pengukuran daripada konstruk yang direpresentasikan dalam ukuran (Podsakoff, MacKenzie, Lee, \& Podsakoff, 2003). CMV menimbulkan masalah konsistensi internal, yaitu keterkaitan yang jelas antara variabel yang dihasilkan oleh sumber yang sama. CMV biasanya terjadi ketika kuesioner laporan mandiri digunakan untuk mengumpulkan data dari responden yang sama pada waktu yang sama. Misalnya, jika peneliti meminta responden untuk mengevaluasi kapabilitas dan kinerja perpustakaan dalam survei yang sama. CMV dapat menyebabkan kesalahan pengukuran sistematis yang menaikkan atau menurunkan tingkat hubungan yang diamati antar konstruk, menghasilkan kesalahan Tipe I dan Tipe II (Chang, Van Witteloostuijn, \& Eden, 2010).

CMV adalah ancaman untuk menghasilkan temuan penelitian yang valid dan reliabel (Spector et al., 2019). Banyak peneliti di bidang Ilmu Perpustakaan dan Informasi masih belum menyadari kegentingan hal ini. Banyak tulisan yang menerbitkan penelitian empiris di bidang ini gagal melaporkan bagaimana penelitian tersebut menangani CMV. Oleh karena itu, tujuan dari penelitian ini adalah untuk menjembatani kesenjangan pengetahuan dengan menggambarkan CMV sebagai tema pokok dalam penelitian perpustakaan dan ilmu informasi. Kajian ini menggambarkan sumber-sumber CMV dan solusi prosedural yang tepat yang dapat digunakan untuk mengendalikan dan meminimalkan CMV.

\section{Metode Penelitian}

Pengembangan keilmuan dalam bidang kepustakaan dan penelitian ilmu informasi mengalami percepatan yang luar biasa, sementara pada waktu yang bersamaan tetap terspesialisasi dan terintegrasi secara interdisipliner. Hal ini menjadikan kesulitan untuk mengikuti penelitian mutakhir dan terdepan, serta melakukan penilaian terhadap bukti kolektif dalam bidang penelitian tertentu. Inilah mengapa sebuah tinjauan pustaka sebagai metode penelitian lebih relevan dari sebelumnya. Tinjauan pustaka secara luas dapat didefiisikan sebagai cara sistematis untuk mengumpulkan dan mensistesis penelitian sebelumnya (Tranfield, Denyer, \& Smart, 2003). Tinjauan pustaka yang efektif dan dilakukan secara baik sebagai sebuah metode penelitian, akan menciptakan dasar yang kuat untuk memajukan pengetahuan dan memfasilitasi pengembangan teori (Webster \& Watson, 2002).

Dengan meningitegrasikan temuan dan perspektif dari banyak temuan empiris, sebuah tinjauan pustaka dapat menjawab pertanyaan penelitian dengan kekuatan yang tidak dimiliki oleh studi tunggal. Sejauh menyangkut tentang metodologi penelitian, studi ini mengadopsi pendekatan tinjauan pustaka secara integratif. Sebagaimana yang ditulis oleh Snyder (2019) bahwa sebagian besar tinjauan pustaka integratif dilakukan untuk membahas topik yang telah mature ataupun topik yang baru muncul dan belum banyak diteliti. Dalam hal topik yang telah mature, tujuan dalam menggunakan tinjauan pustaka integratif adalah untuk melakukan kajian terhadap dasar kelimuan, meninjau secara kritis, melakukan redefinisi, dan memperluas landasan teoritis dari topik tertentu yang sedang berkembang. Snyder (2019) kemudian menekankan bahwa meskipun tidak ada yang standar yang ketat dalam melakukan kajian integratif, akan tetapi tujuan umumnya adalah untuk menganalisis secara kritis, memeriksa literatur serta gagasan utama, dan hubungan kausalitas dari 
Palimpsest: Journal of Information and Library Science Vol. 12, Issue 1, 2021, page 3-72

suatu masalah. Oleh karena itu langkah-langkah yang disarankan Snyder (2019), yaitu 1) merancang review, 2) melakukan review, 3) analisis dan 4) menuliskan review dalam sebuah bidang penelitian.

\section{Hasil dan Pembahasan}

\section{Sumber CMV}

Empat sumber umum CMV telah ditetapkan oleh Podsakoff et al. (2003) dan Podsakoff, MacKenzie \& Podsakoff (2012): 1) penggunaan responden yang sama untuk mengumpulkan data untuk variabel dependen dan independent, 2) cara penyajian butir pertanyaan atau pernyataan, 3) konteks di mana pertanyaan atau pernyataan tersebut dimasukkan ke dalam kuesioner, 4) dampak kontekstual (media, waktu, dan tempat) yang digunakan untuk pengukuran konstruk (Chang, Van Witteloostuijn, \& Eden, 2010). Masing-masing dari empat sumber CMV ini memiliki tingkat masalahnya masing-masing. Pengumpulan data yang menggunakan ukuran persepsi dari satu sumber dianggap paling bermasalah dibandingkan dengan yang lain.

Menurut Malhotra, Schaller \& Patil (2017) sumber yang mendasari CMV cenderung berada dalam studi berbasis survei silang-sekat atau cross-sectional. Kuesioner panjang yang digunakan selama studi silang-sekat untuk mengumpulkan data dari sampel mungkin merupakan sumber CMV lain. Secara umum, kuesioner membutuhkan upaya kognitif yang signifikan untuk menghasilkan tanggapan yang akurat, dan pada akhir kuesioner yang panjang, para responden mungkin merasa lelah. Oleh karena itu, mereka kurang bersedia untuk menjawab dengan jujur dan sungguh-sungguh. Akibatnya, para responden mungkin kehilangan konsentrasi dan memberikan jawaban yang lebih konsisten dalam ukuran skala, dan mungkin juga pengukuran lintas skala (Viswanathan dan Kayande, 2012) Tanggapan semacam itu biasanya disebut tanggapan straightlining (garis lurus) dan dapat menyebabkan interpretasi yang salah tentang validitas dan reliabilitas skala, maupun jalur kausal dan moderasi antar konstruk (Rodríguez-Ardura \& MeseguerArtola, 2020).

Sumber CMV lain yang memungkinkan meliputi kemampuan responden yang terbatas untuk menanggapi pertanyaan skala, kompleksitas pertanyaan dalam skala, ambiguitas pertanyaan, pertanyaan berlaras ganda, pertanyaan yang memerlukan memori retrospektif, kurangnya pengalaman responden dalam berpikir terkait topik yang sedang dibahas, dan rendahnya partisipasi responden dalam sebuah topik (Rodríguez-Ardura \& Meseguer-Artola, 2020). Selain itu, sumber potensial CMV lainnya adalah karena peletakan konstruk kriteria butir pertanyaan atau pernyataan dalam skala yang menonjol (sehingga responden menyimpulkan bahwa ada hubungan kausal dengan konstruk lain), pemahaman responden ketika dievaluasi, keengganan responden untuk mengungkapkan diri, kebutuhan responden untuk menunjukkan perilaku yang dapat diterima secara sosial, kecenderungan responden untuk setuju (atau tidak setuju) dengan pernyataan apa pun yang dibuat dalam butir pertanyaan atau pernyataan dalam skala terlepas dari kepuasaan mereka, kecenderungan responden untuk memberikan tanggapan yang fanatik, anggapan implisit responden tentang topik tersebut, dan kesediaan responden untuk memberikan jawaban yang konsisten atas serangkaian pertanyaan (Rodríguez-Ardura \& Meseguer-Artola, 2020).

\section{Perbaikan untuk Mengendalikan atau Meminimalkan CMV}

Banyak peneliti telah mengidentifikasi dua pendekatan utama yang dapat digunakan untuk mengontrol atau meminimalkan CMV, yaitu perbaikan preventif dan perbaikan statistik. Upaya preventif berkaitan dengan desain penelitian, terutama pada pengembangan kuesioner dan pemilihan responden untuk menjawab kuesioner. Perbaikan prosedural dilakukan sebelum pengumpulan data studi, sementara perbaikan statistik diterapkan setelah pengumpulan data selesai dan melibatkan pengerjaan statistik tertentu pada data (Lindell \& Whitney, 2001; Sehahnaz, Ramayah, \& Sajilan, 
2017). Fuller et al. (2016) menganjurkan penggunaan perbaikan prosedural dan statistik untuk mengontrol dan meminimalkan CMV.

Pertanyaan atau pernyataan yang mengukur variabel bebas (prediktor) dan pertanyaan atau peryataan yang mengukur variabel terikat (kriteria) mungkin berkaitan karena format atau kata-kata tertentu, struktur pengukuran kuesioner, atau responden (Podsakof et al., 2003). Oleh karena itu, beberapa perbaikan preventif telah disarankan seperti yang tertera di bawah ini. Sebagai gambaran tentang bagaimana langkah-langkah ini dapat diterapkan, penulis menyajikan sebuah penelitian yang menelaah hubungan antara kompetensi dan prestasi kerja pustakawan. Penelitian ini memiliki dua variabel bebas yaitu kompetensi profesional dan kompetensi personal dan satu variabel terikat yaitu prestasi kerja (Gambar 1). Butir pertanyaan atau pernyataan yang digunakan untuk mengukur variabel tersebut disajikan pada Tabel 1, 2, dan 3.

\section{Variabel Bebas}

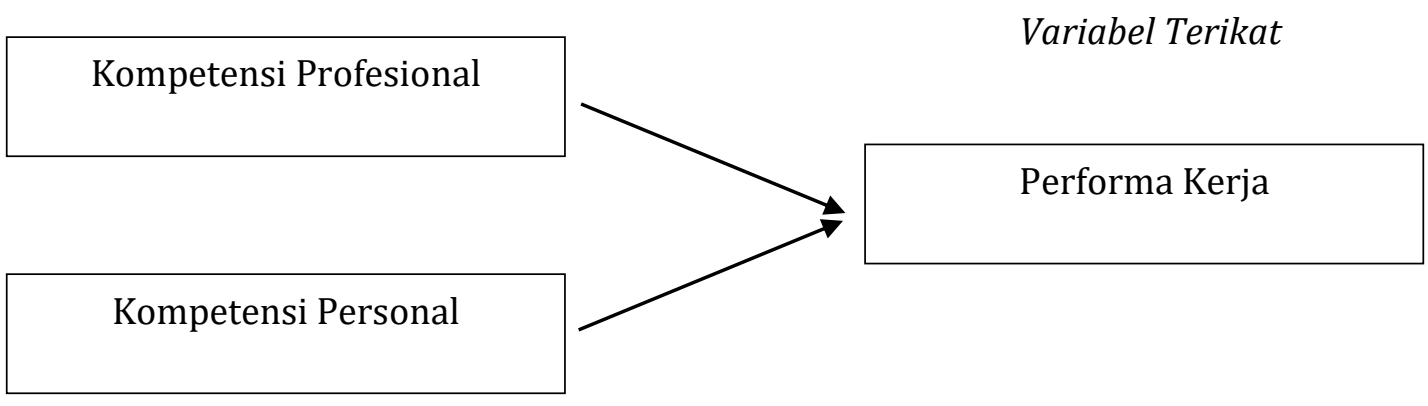

Variabel Bebas

Gambar 1.

Model penelitian

Tabel 1.

Pernyataan yang mengukur performa kerja

\begin{tabular}{|l|c|c|c|c|c|c|c|}
\hline $\begin{array}{l}\text { Silakan beri penilaian performa } \\
\text { kerja berdasarkan kriteria berikut: }\end{array}$ & $\begin{array}{c}(1) \\
\text { Sangat } \\
\text { Buruk }\end{array}$ & $\begin{array}{c}(2) \\
\text { Buruk }\end{array}$ & $\begin{array}{c}\text { (3) } \\
\text { Agak } \\
\text { Buruk }\end{array}$ & $\begin{array}{c}(4) \\
\text { Sedang }\end{array}$ & $\begin{array}{c}(5) \\
\text { Agak } \\
\text { Istimewa }\end{array}$ & $\begin{array}{c}(6) \\
\text { Istimewa }\end{array}$ & $\begin{array}{c}\text { Sangat } \\
\text { Istimewa }\end{array}$ \\
\hline $\begin{array}{l}\text { Kuantitas pekerjaan yang } \\
\text { dihasilkan }\end{array}$ & & & & & & & \\
\hline $\begin{array}{l}\text { Kualitas pekerjaan yang } \\
\text { dihasilkan }\end{array}$ & & & & & & & \\
\hline 3. Efektivitas pemberian layanan & & & & & & & \\
\hline 4. Efisiensi pemberian layanan & & & & & & & \\
\hline
\end{tabular}

Tabel 2.

Pernyataan yang mengukur kompetensi professional

\begin{tabular}{|l|c|c|c|c|c|}
\hline $\begin{array}{l}\text { Silakan beri penilaian kompetensi berdasarkan } \\
\text { kriteria berikut: }\end{array}$ & $\begin{array}{c}(1) \\
\text { Sangat } \\
\text { Rendah }\end{array}$ & $\begin{array}{c}(2) \\
\text { Rendah }\end{array}$ & $\begin{array}{c}(3) \\
\text { Sedang }\end{array}$ & $\begin{array}{c}(4) \\
\text { Tinggi }\end{array}$ & $\begin{array}{c}(5) \\
\text { Sangat } \\
\text { Tinggi }\end{array}$ \\
\hline 1. Pemerolehan dan pemrosesan & & & & & \\
\hline 2. Pengembangan Koleksi & & & & & \\
\hline
\end{tabular}


Palimpsest: Journal of Information and Library Science Vol. 12, Issue 1, 2021, page 5-11

\begin{tabular}{|l|c|c|c|c|c|}
\hline $\begin{array}{l}\text { Silakan beri penilaian kompetensi berdasarkan } \\
\text { kriteria berikut: }\end{array}$ & $\begin{array}{c}(1) \\
\text { Sangat } \\
\text { Rendah }\end{array}$ & $\begin{array}{c}(2) \\
\text { Rendah }\end{array}$ & $\begin{array}{c}(3) \\
\text { Sedang }\end{array}$ & $\begin{array}{c}(4) \\
\text { Tinggi }\end{array}$ & $\begin{array}{c}(5) \\
\text { Sangat } \\
\text { Tinggi }\end{array}$ \\
\hline 3. Katalogisasi dan Klasifikasi & & & & & \\
\hline 4. Pelatihan Literasi Informasi & & & & & \\
\hline
\end{tabular}

Tabel 3.

Pernyataan yang mengukur kompetensi personal

\begin{tabular}{|c|c|c|c|c|c|c|c|}
\hline $\begin{array}{l}\text { Silakan beri penilaian sejauh mana } \\
\text { Anda setuju atau tidak setuju dengan } \\
\text { pernyataan berikut: }\end{array}$ & $\begin{array}{l}(1) \\
\text { Sangat } \\
\text { Tidak } \\
\text { Setuju }\end{array}$ & $\begin{array}{c}(2) \\
\text { Tidak } \\
\text { Setuju }\end{array}$ & $\begin{array}{l}\text { (3) } \\
\text { Agak } \\
\text { Tidak } \\
\text { Setuju }\end{array}$ & $\begin{array}{l}\text { (4) } \\
\text { Netral }\end{array}$ & $\begin{array}{c}\text { (5) } \\
\text { Agak } \\
\text { Setuju }\end{array}$ & $\begin{array}{c}(6) \\
\text { Setuju }\end{array}$ & $\begin{array}{c}(7) \\
\text { Sangat } \\
\text { Setuju }\end{array}$ \\
\hline $\begin{array}{l}\text { Saya dapat dengan mudah } \\
\text { berkomunikasi dengan orang- } \\
\text { orang dari semua golongan }\end{array}$ & & & & & & & \\
\hline $\begin{array}{l}\text { 2. Saya tidak mengalami kesulitan } \\
\text { dalam memahami emosi orang lain }\end{array}$ & & & & & & & \\
\hline $\begin{array}{l}\text { 3. Saya tidak mengalami kesulitan } \\
\text { dalam mengatur sejumlah } \\
\text { bawahan }\end{array}$ & & & & & & & \\
\hline $\begin{array}{l}\text { 4. Saya yakin dapat membuat } \\
\text { keputusan untuk masalah atau } \\
\text { persoalan apa pun }\end{array}$ & & & & & & & \\
\hline
\end{tabular}

Berikut adalah beberapa pilihan yang dapat diambil oleh seorang peneliti. Prosedur tertentu dapat digabungkan dalam satu penelitian.

- Mengumpulkan data dari berbagai sumber. Jika keadaan memungkinkan, libatkan setidaknya dua sumber berbeda untuk mengisi kuesioner yang sama, pertanyaan terkait variabel bebas akan dijawab oleh sumber pertama sedangkan pertanyaan tentang variabel terikat akan dijawab oleh sumber kedua. Pertanyaan mengenai kompetensi profesional dan personal (variabel bebas) harus dijawab oleh pustakawan perorangan sedangkan pertanyaan terkait prestasi kerja (variabel terikat) harus dijawab oleh supervisor atau atasan para pustakawan.

- Jika tidak memungkinkan untuk melibatkan banyak sumber, pisahkan waktu antara pengumpulan data untuk variabel bebas dan variabel terikat. Berdasarkan contoh di atas, jika sulit untuk melibatkan supervisor atau atasan, maka pustakawan sendiri dapat menjawab semua pertanyaan, namun waktu pengumpulan data untuk kompetensi profesional dan personal (variabel independen) harus dipisahkan dari waktu pengumpulan data untuk prestasi kerja (variabel terikat). Dengan kata lain, pengumpulan data akan dibagi menjadi dua tahap yang berbeda, yang pertama tahap pengumpulan variabel bebas dan yang kedua adalah pengumpulan variabel terikat.

- Pemisahan secara metodologis antara pengumpulan data untuk variabel bebas dan variabel terikat. Untuk pengumpulan data yang mengukur kompetensi profesional dan personal (variabel bebas), peneliti dapat menggunakan kuesioner tertulis atau daring. Namun untuk pengumpulan data yang mengukur prestasi kerja (variabel terikat), peneliti harus melakukan wawancara tatap muka yang terstruktur dengan para pustakawan. 
- Alih-alih menggunakan metode ganda untuk pengumpulan data, metode mono masih dapat digunakan, tetapi format pertanyaan yang digunakan untuk pertanyaan yang mengukur variabel bebas versus item yang digunakan untuk mengukur variabel terikat harus berbeda. Misalnya, jika jenis pertanyaan skala Likert digunakan, kompetensi profesional dan personal (variabel bebas) mungkin harus mengukur tingkat persetujuan atau ketidaksetujuan, sementara prestasi kerja (variabel terikat) harus memberikan penilaian tingkat intensitas frekuensi. Merupakan hal yang tepat menggunakan jumlah anchoring atau pilihan yang berbeda pada skala Likert, seperti lima pilihan untuk kompetensi profesional dan personal (variabel bebas) dan tujuh pilihan untuk prestasi kerja (variabel terikat). Contoh seperti yang disajikan pada Tabel 1, 2, dan 3 semuanya menggunakan jumlah anchoring dan pelabelan yang berbeda.

- Skala pengukuran variabel bebas dan terikat harus diperoleh dari sumber yang berbeda. Skala yang diambil dari sumber yang sama biasanya menunjukkan pola kesamaan dalam hal penggunaan kata dan struktur frase meskipun dimaksudkan untuk mengukur konstruk atau variabel yang berbeda. Oleh karena itu, responden dapat memprediksi jawaban pertanyaan tentang variabel bebas setelah menyelesaikan pertanyaan tentang variabel terikat, atau sebaliknya. Mengacu pada ilustrasi di atas maka butir-butir pertanyaan atau pernyataan yang mengukur kompetensi profesional dan personal harus diperoleh dari sumber A, sedangkan butir-butir pertanyaan atau pernyataan yang mengukur prestasi kerja diperoleh dari sumber B, serta sumber A dan sumber B tidak boleh orang yang sama.

- Penggunaan surat lamaran dengan penjelasan atau instruksi yang sesuai juga merupakan hal yang tepat untuk meminimalkan CMV. Penjelasan harus diberikan bahwasanya tidak ada jawaban yang benar atau salah karena ini akan membantu mengurangi keengganan responden untuk dievaluasi dan membuat mereka cenderung tidak memberikan jawaban yang konsisten di seluruh pertanyaan. Demikian pula, peneliti harus memberi tahu responden bahwa data yang dikumpulkan akan dilindungi, dikumpulkan, dan digunakan dengan aman hanya untuk tujuan penelitian, karena hal ini memungkinkan calon responden untuk berpartisipasi dan memberikan jawaban yang sebenar-benarnya.

- Skala atau kuesioner harus diujicobakan terlebih dahulu dengan dua kelompok orang, yaitu para ahli dan calon responden. Kelompok orang tersebut akan dilibatkan untuk memberikan komentar dan masukan terkait kejelasan dan relevansi konten; format dan jenis pertanyaan yang digunakan; panjang pertanyaan; bahasa dan waktu yang diperlukan untuk menjawab kuesioner. Skala atau kuesioner harus ditinjau kembali berdasarkan masukan mereka. Lampiran 1 menyajikan contoh formulir yang dapat digunakan untuk pre-test yang diadaptasi dari Polit \& Beck (2006).

\section{Simpulan}

Para peneliti yang menggunakan survei silang-sekat (cross-sectional) tidak bisa mengesampingkan dampak CMV dan oleh karena itu, harus menggunakan teknik yang meyakinkan dalam membantu mencegah dan mengendalikan CMV. Mereka harus menyadari kelebihan dan keterbatasan masing-masing metode ini. Penerapan berbagai prosedur pencegahan sangat dianjurkan sebagai tindakan yang layak dan efektif untuk menangani CMV guna memberikan temuan yang valid di bidang teori perpustakaan dan ilmu informasi. Selain itu, para peneliti juga dapat menerapkan metode prosedural tetapi hal tersebut tidak dibahas dalam lingkup penelitian ini.

\section{Daftar Pustaka}


Chang, S. J., Van Witteloostuijn, A., \& Eden, L. (2010). From the editors: Common method variance in international business research. Journal of International Business Studies, 41 (2), 178-184.

Fuller, C.M., Simmering, M.J., Atinc, G., Atinc, Y. and Babin, B.J. (2016). Common Methods Variance Detection In Business Research. Journal of Business Research, 69(8), 3192-3198.

Lindell, M.K. and Whitney, D.J. (2001). Accounting for common method variance in cross-sectional research designs. Journal of Applied Psychology, 86(1), 114-121.

Malhotra, N.K., Schaller, T.K. and Patil, A. (2017). Common Method Variance In Advertising Research: When To Be Concerned And How To Control For It. Journal of Advertising, 46(1) 193-212.

Podsakoff, P.M., MacKenzie, S.B., Lee, J.Y., \& Podsakoff, N.P. (2003). Common method biases in behavioral research: A critical review of the literature and recommended remedies. Journal of Applied Psychology, 88 (5), 879-903.

Podsakoff, P.M., MacKenzie, S.B. and Podsakoff, N.P. (2012). Sources of Method Bias In Social Science Research And Recommendations On How To Control It. Annual Review of Psychology, 63(1), 539-569, 2012.

Polit, D.F. and Beck, C.T. (2006). The Content Validity Index: Are you sure you know what's being reported? Critique and recommendations. Research in Nursing \& Health, 25(9), 489-497.

Rodríguez-Ardura, I. and Meseguer-Artola, A. (2020). Editorial: How to Prevent, Detect and Control Common Method Variance in Electronic Commerce Research. Journal of Theoretical and Applied Electronic Commerce Research, 15(2), 1-6.

Sehahnaz, T., Ramayah, T. and Sajilan, S. (2017). Testing and Controlling for Common Method Variance: A Review of Available Method. Journal of Management Sciences, 4(2), 142-168.

Snyder, H. (2019). Literature review as a research methodology: an overview. Journal of Business Research, 104, 333-339.

Spector, P.E., Rosen, C.C., Richardson, H.A., Williams, L.J. and Johnson, R.E. (2019) A new perspective on method variance: A measure-centric approach. Journal of Management, 45(3), 855-880, 2019.

Tranfield, D., Denyer, D., \& Smart, P. (2003). Towards a methodology for developingevidenceinformed management knowledge by means of systematic review. British Journal of Management, 14, 207-222.

Viswanathan, M and Kayande, U. (2012). Commentary On Common Method Bias In Marketing: Causes, Mechanisms And Procedural Remedies. Journal of Retailing, 88(4), 556-562.

Webster, J. and Watson, R.T. (2002). Analyzing the past to prepare for the future: writing a literature review. Management Information Systems Quarterly, 26(3), 13-23.

Whittemore, R. and Knafl. K. (2005). The integrative review: updated methodology. Journal of Advanced Nursing, 52, 546 -553. 


\section{HUBUNGAN ANTARA KOMPETENSI DAN PRESTASI KERJA PUSTAKAWAN FORMULIR PRE-TEST}

Tabel 1. Usulan tujuan penelitian dan pertanyaan penelitian untuk penelitian yang direncanakan

\begin{tabular}{|l|l|l|}
\hline \multicolumn{2}{|c|}{ TUJUAN PENELITIAN } & PERTANYAAN PENELITIAN \\
\hline 1. & $\begin{array}{l}\text { Untuk mengetahui bagaiamana para pustakawan memberi } \\
\text { penilaian terhadap prestasi kerja, kompetensi personal dan } \\
\text { teknis }\end{array}$ & $\begin{array}{l}\text { Bagaiamana para pustakawan memberi penilaian terhadap } \\
\text { prestasi kerja, kompetensi personal dan teknis? }\end{array}$ \\
\hline 2. & $\begin{array}{l}\text { Untuk menelaah pengaruh kompetensi para pustakawan } \\
\text { terhadap prestasi kerja }\end{array}$ & $\begin{array}{l}\text { Bagaimana kompetensi para pustakawan memengaruhi prestasi } \\
\text { kerja? }\end{array}$ \\
\hline
\end{tabular}

\section{KERANGKA PENELITIAN}

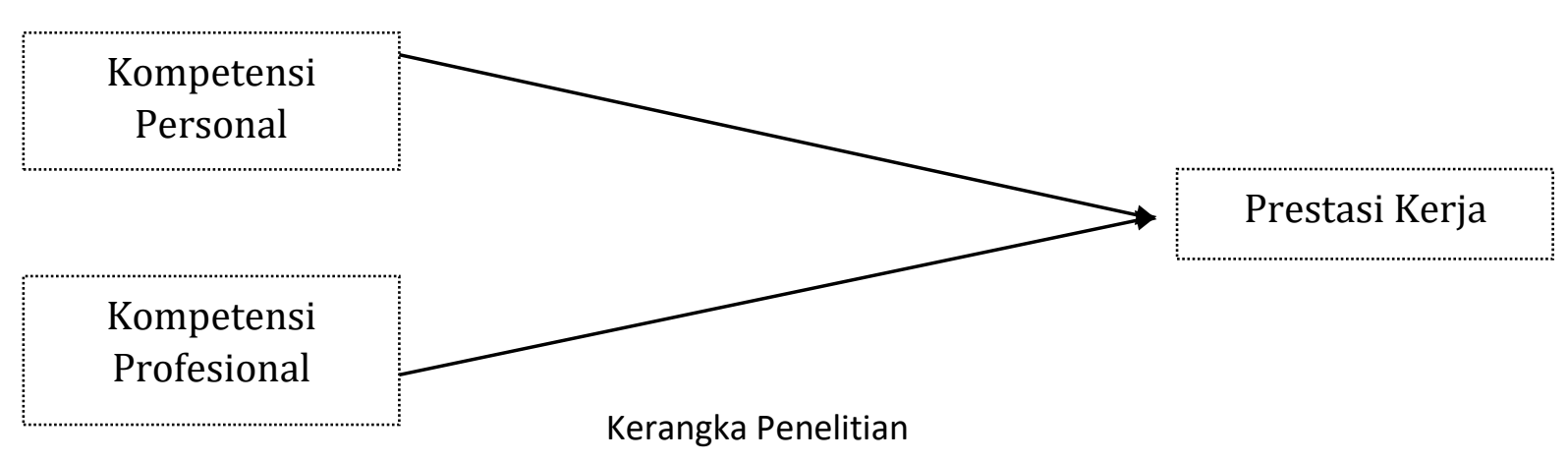

BAGIAN A. PRESTASI KERJA

Petunjuk: Silakan beri penilaian prestasi kerja berdasarkan kriteria berikut: 
Palimpsest: Journal of Information and Library Science Vol. 12, Issue 1, 2021, page 9-11

\begin{tabular}{|c|c|c|c|c|c|c|c|c|c|c|}
\hline \multirow{4}{*}{$\begin{array}{l}\text { Variabel dan Definisi } \\
\text { Operasional }\end{array}$} & \multicolumn{10}{|c|}{$\begin{array}{c}\text { Skala yang digunakan: } \\
\text { (1) Sangat Buruk (2) Buruk (3) Agak Buruk (4) Sedang (5) Agak Istimewa (6) Istimewa (7) Sangat Istimewa }\end{array}$} \\
\hline & \multirow[b]{3}{*}{ Butir Pernyataan Kuesioner } & \multicolumn{8}{|c|}{$\begin{array}{l}\text { Penilaian Anda } \\
\text { (Mohon centang }(\sqrt{ }) \text { mana yang sesuai) }\end{array}$} & \multirow[t]{3}{*}{ Komental } \\
\hline & & \multicolumn{4}{|c|}{ Relevansi } & \multicolumn{4}{|c|}{ Kejelasan } & \\
\hline & & $\begin{array}{c}(1) \\
\text { Tidak } \\
\text { relevan } \\
\text { sama } \\
\text { sekali }\end{array}$ & $\begin{array}{c}\text { (2) } \\
\text { Pernyataan } \\
\text { perlu } \\
\text { beberapa } \\
\text { revisi }\end{array}$ & $\begin{array}{c}\text { (3) } \\
\text { Relevan } \\
\text { tetapi } \\
\text { perlu } \\
\text { sedikit } \\
\text { revisi }\end{array}$ & $\begin{array}{c}(4) \\
\text { Sangat } \\
\text { Relevan }\end{array}$ & $\begin{array}{c}(1) \\
\text { Tidak } \\
\text { Jelas }\end{array}$ & $\begin{array}{c}(2) \\
\text { Pernyataa } \\
\mathrm{n} \text { perlu } \\
\text { beberapa } \\
\text { revisi }\end{array}$ & $\begin{array}{c}\text { (3) } \\
\text { Jelas } \\
\text { tetapi } \\
\text { perlu } \\
\text { sedikit } \\
\text { revisi }\end{array}$ & $\begin{array}{c}(4) \\
\text { Sangat } \\
\text { jelas }\end{array}$ & \\
\hline \multirow{4}{*}{$\begin{array}{l}\text { Prestasi kerja adalah } \\
\text { keluaran dan } \\
\text { pelayanan } \\
\text { pustakawan yang } \\
\text { dinilai dari segi } \\
\text { kuantitas, kualitas, } \\
\text { efisiensi dan } \\
\text { efektivitas }\end{array}$} & $\begin{array}{l}\text { 1. Kuantitas kerja yang } \\
\text { dihasilkan }\end{array}$ & & & & & & & & & \\
\hline & $\begin{array}{l}\text { 2. Kualitas kerja yang } \\
\text { dihasilkan }\end{array}$ & & & & & & & & & \\
\hline & $\begin{array}{l}\text { 3. Efektivitas pemberian } \\
\text { layanan }\end{array}$ & & & & & & & & & \\
\hline & 4. Efisiensi pemberian layanan & & & & & & & & & \\
\hline
\end{tabular}

\section{BAGIAN B. PROFESSIONAL COMPETENCIES}

Petunjuk: Silakan beri penilaian kompetensi berdasarkan kriteria berikut:

Skala yang digunakan:

(1) Sangat rendah (2) Rendah (3) Sedang (4) Tinggi (5) Sangat tinggi

\begin{tabular}{|l|c|c|c|}
\hline \multirow{2}{*}{ Butir Pernyataan Kuesioner } & \multicolumn{2}{|c}{ Variabel dan Definisi Operasional } \\
\cline { 3 - 5 } & & \multicolumn{2}{|c|}{ Penilaian Anda } \\
\cline { 3 - 4 } & & Kohon centang $(\sqrt{ })$ mana yang sesuai) \\
\hline
\end{tabular}


Palimpsest: Journal of Information and Library Science Vol. 12, Issue 1, 2021, page 10-11

\begin{tabular}{|c|c|c|c|c|c|c|c|c|c|c|}
\hline & & $\begin{array}{c}(1) \\
\text { Tidak } \\
\text { relevan } \\
\text { sama } \\
\text { sekali }\end{array}$ & $\begin{array}{c}\text { (2) } \\
\text { Pernyataa } \\
\text { n perlu } \\
\text { beberapa } \\
\text { revisi }\end{array}$ & $\begin{array}{c}(3) \\
\text { Relevan } \\
\text { tetapi } \\
\text { perlu } \\
\text { sedikit } \\
\text { revisi }\end{array}$ & $\begin{array}{c}(4) \\
\text { Sangat } \\
\text { Relevan }\end{array}$ & $\begin{array}{c}(1) \\
\text { Tidak } \\
\text { Jelas }\end{array}$ & $\begin{array}{c}\text { (2) } \\
\text { Pernyataa } \\
\text { n perlu } \\
\text { beberapa } \\
\text { revisi }\end{array}$ & $\begin{array}{c}\text { (3) } \\
\text { Jelas } \\
\text { tetapi } \\
\text { perlu } \\
\text { sedikit } \\
\text { revisi }\end{array}$ & $\begin{array}{c}(4) \\
\text { Sang } \\
\text { at } \\
\text { jelas }\end{array}$ & \\
\hline \multirow{4}{*}{$\begin{array}{l}\text { Kompetensi profesional } \\
\text { adalah kompetensi } \\
\text { teknis yang dibutuhkan } \\
\text { oleh pustakawan untuk } \\
\text { melaksanakan tugas } \\
\text { kepustakawanan } \\
\text { profesional seperti } \\
\text { pembuatan katalog, } \\
\text { klasifikasi dll. }\end{array}$} & $\begin{array}{l}\text { 1. Pemerolehan dan } \\
\text { Pemrosesan }\end{array}$ & & & & & & & & & \\
\hline & 2. Pengembangan Koleksi & & & & & & & & & \\
\hline & 3. Katalogisasi dan Klasifikasi & & & & & & & & & \\
\hline & 4. Pelatihan Literasi Informasi & & & & & & & & & \\
\hline
\end{tabular}

\section{BAGIAN B. KOMPETENSI PERSONAL}

Petunjuk: Silakan beri penilaian sejauh mana Anda setuju atau tidak setuju dengan pernyataan berikut:

\begin{tabular}{|c|c|c|c|c|c|c|c|c|c|c|}
\hline \multirow[b]{4}{*}{$\begin{array}{l}\text { Variabel dan Definisi } \\
\text { Operasional }\end{array}$} & \multicolumn{9}{|c|}{$\begin{array}{l}\text { Skala yang digunakan: } \\
\text { uju (3) Agak tidak setuju (4) Netral (5) Agak setuju (6) Setuju (7) Sangat setuju }\end{array}$} & \\
\hline & \multirow[b]{3}{*}{ Butir Pernyataan Kuesioner } & \multicolumn{8}{|c|}{$\begin{array}{c}\text { Penilaian Anda } \\
\text { (Mohon centang }(\sqrt{ }) \text { mana yang sesuai) }\end{array}$} & \multirow[t]{3}{*}{ Komenta } \\
\hline & & \multicolumn{4}{|c|}{ Relevansi } & \multicolumn{4}{|c|}{ Clarity } & \\
\hline & & $\begin{array}{l}\text { (1) } \\
\text { Tidak } \\
\text { relevan } \\
\text { sama } \\
\text { sekali }\end{array}$ & $\begin{array}{l}\text { (2) } \\
\text { Pernyataa } \\
\mathrm{n} \text { perlu } \\
\text { beberapa } \\
\text { revisi }\end{array}$ & $\begin{array}{l}\text { (3) } \\
\text { Tidak } \\
\text { relevan } \\
\text { sama } \\
\text { sekali }\end{array}$ & $\begin{array}{c}\text { (4) } \\
\text { Sangat } \\
\text { Relevan }\end{array}$ & $\begin{array}{c}(1) \\
\text { Tidak } \\
\text { Jelas }\end{array}$ & $\begin{array}{l}\text { (2) } \\
\text { Pernyataa } \\
\mathrm{n} \text { perlu } \\
\text { beberapa } \\
\text { revisi }\end{array}$ & $\begin{array}{l}\text { (3) } \\
\text { Jelas } \\
\text { tetapi } \\
\text { perlu } \\
\text { sedikit } \\
\text { revisi }\end{array}$ & $\begin{array}{l}(4) \\
\text { Sanga } \\
\text { t jelas }\end{array}$ & \\
\hline $\begin{array}{l}\text { Kompetensi personal } \\
\text { merupakan } \\
\text { keterampilan nonteknis } \\
\text { yang dibutuhkan }\end{array}$ & $\begin{array}{l}\text { 1. Saya dapat dengan mudah } \\
\text { berkomunikasi dengan } \\
\text { orang-orang dari semua } \\
\text { golongan }\end{array}$ & & & & & & & & & \\
\hline
\end{tabular}


Palimpsest: Journal of Information and Library Science Vol. 12, Issue 1, 2021, page 11-11

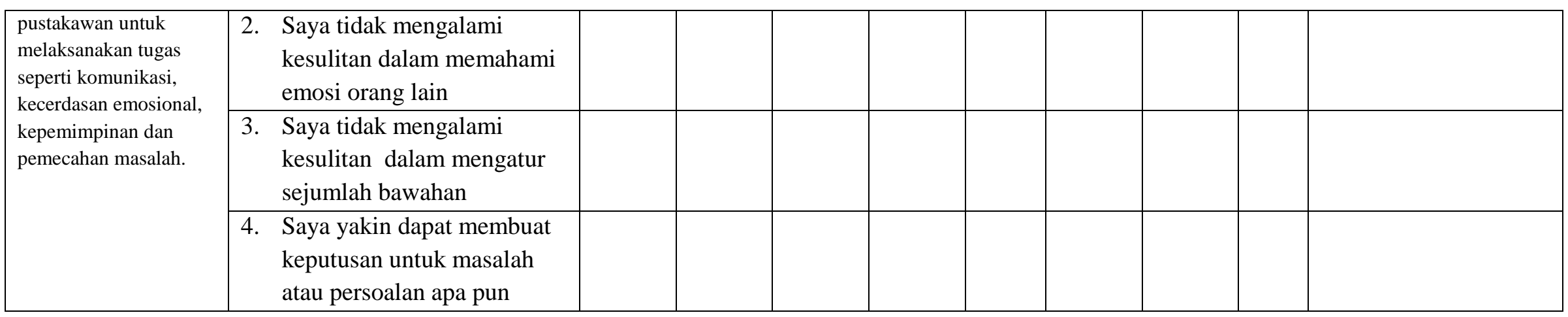

- Keseluruhan waktu yang dibutuhkan untuk menyelesaikan instrumen:

- Rekomendasi ukuran font:

Tetap

Ubah menjadi lebih besar

Ubah menjadi lebih kecil

- Bahasa yang digunakan dalam kuesioner:

Bahasa

Inggris

Bahasa Indonesia

Dwibahasa (Bahasa Inggris and Bahasa Indonesia)

Dengan menandatangani ini: Saya menyatakan bahwa informasi di atas akurat dan lengkap. 